\title{
UPPER PALEOLITHIC OCCUPATION LEVELS AND LATE-OCCURRING NEANDERTAL AT VINDIJA CAVE (CROATIA) IN THE CONTEXT OF CENTRAL EUROPE AND THE BALKANS
}

\author{
Ivor Karavanic \\ Department of Archaeology, Faculty of Philosophy, University of Zagreb, I. Lucica 3, RO. Box \\ 171, 41000 Zagreb, Croatia
}

This paper presents the results obtained by analysis of Upper Paleolithic occupation levels in Vindija Cave, northwestern Croatia. Typological analyses of stone and bone tools have been carried out. Vindija provides direct evidence on the transition from the Middle Paleolithic to the Upper Paleolithic, as well as on fossil hominids (probably Neanderthals) associated with a 33,000-year-old Upper Paleolithic (Aurignacian) industry. The Upper Paleolithic of this site starts with the Aurignacian and continues with the Gravettian industry, which is divided into several phases (Gravettian, Late Gravettian, and final Gravettian/Epigravettian). The topmost levels pertain to the Holocene. These industries at Vindija display both some similarities to, but also some differences from, concurrent industries found in Central European sites. There are notable differences between the Upper Paleolithic at Vindija and Paleolithic sites in the Adriatic-Mediterranean region.

THE HRVATSKO ZAGORJE region in northwestern Croatia is known, as evidenced by numerous reports, for Paleolithic sites significant for the evolution of Upper Pleistocene hominids (Jelinek1969; Smith 1982, 1984) and their material cultures (Malez 1978; Simek 1991). The most important sites of the area include Krapina, Veternica, Velika Pecina, and Vindija (Figure 1, nos. 1-4). The results obtained from study of Neanderthal remains (Gorjanovic-Kramberger 1906; Malez 1971; Smith 1976; Wolpoff 1980) and Mousterian artifacts (Gorjanovic-Kramberger 1913; Malez 1970,1978; Simek 1991) discovered at Krapina have been reported in many publications. Veternica Cave yielded Mousterian artifacts. The presence of both Middle and Upper Paleolithic has been established at Velika Pecina, where remains of early modern man have been found in the Aurignacian level.

Both Middle and Upper Paleolithic assemblages are also present at the Vindija site. Vindija Cave is one of the rare European sites that has remains of fossil hominids associated with the stone and bone industries. Therefore, it is very important for solving the problems of the development of Upper Paleolithic technology and of the origins of modern Europeans (see Allsworth-Jones 1986; Brose and Wolpoff 1971; Straus 1989). Remains of Neanderthal and of early modern humans found in Vindija Cave have been analyzed in detail (Malez et al. 1980; Malez and Ullrich 1982; Smith, Boyd, and Malez 1985; Wolpoff et al. 1981). Fossil human remains found in Upper Paleolithic level G1, whose taxonomic position (Neanderthal or early modern) is controversial (Smith 1982,1984;

(Journal of Anthropological Research, vol. 51, 1995) 


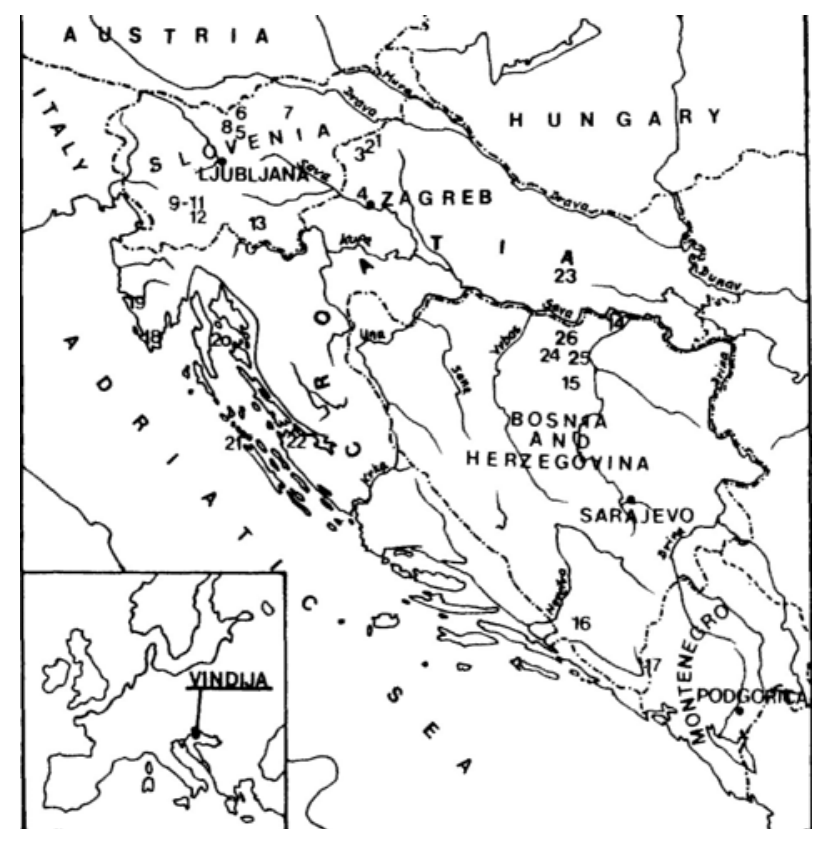

Figure 1. Important Middle and Upper Paleolithic Sites of Croatia, Slovenia, Bosnia and Herzegovina, and Montenegro.

1. Vindija (Middle and Upper Paleolithic)

2. Velika Pecina (Middle Paleolithic)

3. Krapina (Middle Paleolithic)

4. Veternica (Middle Paleolithic)

5. Babja Jama (Upper Paleolithic)

6. Potocka Zijalka (Upper Paleolithic)

7. Spehovka (Upper Paleolithic)

8. MokriSka Jama (Upper Paleolithic)

9. Betalov Spodmol (Middle and Upper Paleolithic)

10. Zupanov Spodmol (Middle and Upper Paleolithic)

11. Ovcja Jama (Upper Paleolithic)

12. Parska Golobina (Middle and Upper Paleolithic)

13. Ciganska Jama (Upper Paleolithic)

14. Kadar (Middle and Upper Paleolithic)

15. Kamen (Middle and Upper Paleolithic)

16. Badanj (Upper Paleolithic)

17. Crvena Stijena (Middle and Upper Paleolithic)

18. Sandalja II (Upper Paleolithic)

19. Romualdova Pecina (Upper Paleolithic)

20. Lopar (Upper Paleolithic)

21. Panjorovica (Upper Paleolithic)

22. Razanac (Middle and Upper Paleolithic)

23. Zarilac (Upper Paleolithic)

24. LuScic (Upper Paleolithic)

25. Londa (Middle and Upper Paleolithic)

26. ZobiSte (Middle Paleolithic) 
Smith and Ahern 1994), deserve perhaps the greatest attention. These remains were found with a number of stone tools with both Middle Paleolithic and Upper Paleolithic typological characteristics, as well as with Upper Paleolithic bone artifacts. This material (like St. Cesaire in France) provides one of the rare examples of an association of Neanderthals with Upper Paleolithic technology. This association may suggest a certain chronological continuity between the different industries, as shown through geological and cultural sequences. It thus places unsolved problems of the Middle to Upper Paleolithic transition in a new light.

The analysis of the Upper Paleolithic tools presented here is based on the typology of D. de Sonneville-Bordes and J. Perrot (1953, 1954, 1955, 1956a, 1956b). The statistical processing of the Upper Paleolithic levels includes all of the stone artifacts excavated by M. Malez and curated at the Institute for Paleontology and Quaternary Geology of the Croatian Academy of Sciences and Arts in Zagreb. Because of the small number of tools found in some individual levels, and because of stratigraphic disturbances due to cryoturbation, it has been thought sufficient to list here the incidence of only the most frequent tools per level and to mention only the most typical items. An exception is level D, which, in the author's view, merits complete statistical and graphic presentation. The analysis of bone tools, originally processed by Malez (1988) with a number of errors in terms of chronological attribution, has also been reviewed. Stone and bone artifacts from Vindija excavated earlier by S. Vukovic (1950) and now at the Varazdin Civic Museum are not covered by this analysis because they cannot be assigned to the stratigraphic units established by excavations supervised by Malez (Malez and Rukavina 1979). ${ }^{1}$

\section{BACKGROUND}

\section{Site Location}

Vindija Cave is situated in Hrvatsko Zagorje, 9.5 linear km northwest of Ivanec, $2 \mathrm{~km}$ west of the village of Donja Voca, and $20 \mathrm{~km}$ west of the center of Varazdin. Its entrance lies in a narrow gorge on the southwestern slope of Kriznjakov Vrh. It is more than $50 \mathrm{~m}$ deep, maximally $28 \mathrm{~m}$ wide, and more than $10 \mathrm{~m}$ high. The entrance to the cave is semicircularly vaulted and about $15 \mathrm{~m}$ wide (Malez 1978).

\section{History of Excavations}

Tools and animal remains were first found in Vindija Cave by S. Vukovic, who first visited the site in autumn 1928. For more than thirty years, with interruptions, he carried out excavations in and in front of the cave, mainly involving the upper levels. The stone material collected by Vukovic has been partly reviewed in a number of reports (Vukovic 1950, 1961, 1970). Excavations

at Vindija Cave supervised by M. Malez started in July 1974. Fieldwork continued every season until 1986 and yielded abundant archaeological and paleontological material, along with fossil human remains. 


\section{STRATIGRAPHY AND CHRONOLOGY}

The stratigraphic interpretation of Vindija is still affected by many unresolved problems, and future stratigraphic explorations may be expected to complete, and maybe even partly change, the results obtained so far. The description of the Upper Paleolithic levels used here is based on the chrono-stratigraphy employed by M. Malez and D. Rukavina (1979). These two scholars used the modified French scheme for division of the Pleistocene, which is often applied in Croatia. With respect to the stratigraphy of Vindija Cave, the French scheme fits well up to stage Wiirm 3. Malez and Rukavina (1979) used the term "Wiirm 3" to denote combined Wiirm 3, Wiirm 3/4, and Wiirm 4 in the French scheme because the stratigraphy of Vindija did not lend itself to a reliable distinction of these oscillations and to a complete observance of the French division. The presence of ecologically mixed faunas, varying in Upper Pleistocene levels depending on climate fluctuations, was noted. Malez and Rukavina (1979) attributed the established sequence of levels to a time span from the onset of the so-called Riss glaciation (oxygen isotope stage 6 or earlier) to the end of the Holocene. Although part of the cave sediment complex was affected by cryoturbation (Malez and Rukavina 1975), the stratigraphic sequence was based on the remaining undisturbed part of the sediment complex (Malez and Rukavina 1979; Rukavina 1983) (Figure 2).

Level Gl of stratigraphic complex $\mathrm{G}$ is the oldest level which can reliably be dated to the Upper Paleolithic. It is a clayey red-brown sediment, $8-20 \mathrm{~cm}$ thick in sectors where the sediments are not disturbed by cryoturbation. Occasionally it contains carbonaceous particles. It was deposited in a warm, humid period and has been attributed to the Wiirm 2/3 interstadial (Malez and Rukavina 1979). A cave bear long bone from level Gl has recently been dated by AMS radiocarbon to $33,000 \pm 400$ B.P. (ETH-12714). The sample was provided by Maja Paunovic (through the cooperation of the Ruder Roskovic Institute and the Institute for Paleontology and Quaternary Geology of the Croatian Academy of Sciences and Arts, both in Zagreb) and was dated at the Swiss Federal Institute of Technology in Zurich through the kindness of Georges Bonani.

Complex F is $30-150 \mathrm{~cm}$ thick and contains a sandy sediment with abundant stone rubble and large stone blocks. It suggests a markedly cold and occasionally humid period (Malez and Rukavina 1979). According to the same scholars, a number of levels can be distinguished within complex F:

$\mathrm{Fd} / \mathrm{d}$ : at this level there is a repeated alternation of thin bands of gray, fairly clayey sediment (containing much small rubble) and green-brown, sandy sediment (with almost no stone rubble). Radiocarbon dating of cave bear bones found in this level yielded an age of $26,600 \pm 900$ B.P. (Z2443) (Obelic et al. 1994).

Fd: sandy sediment with abundant large and small cryoclastic rubble and large stone blocks. Thin, yellow-green lenses have been observed within the level. Radiocarbon dating of a sample of charcoal found between levels Fd and Fd/d, according to Malez and Rukavina (1979), or in level $\mathrm{Fd}$, according to 


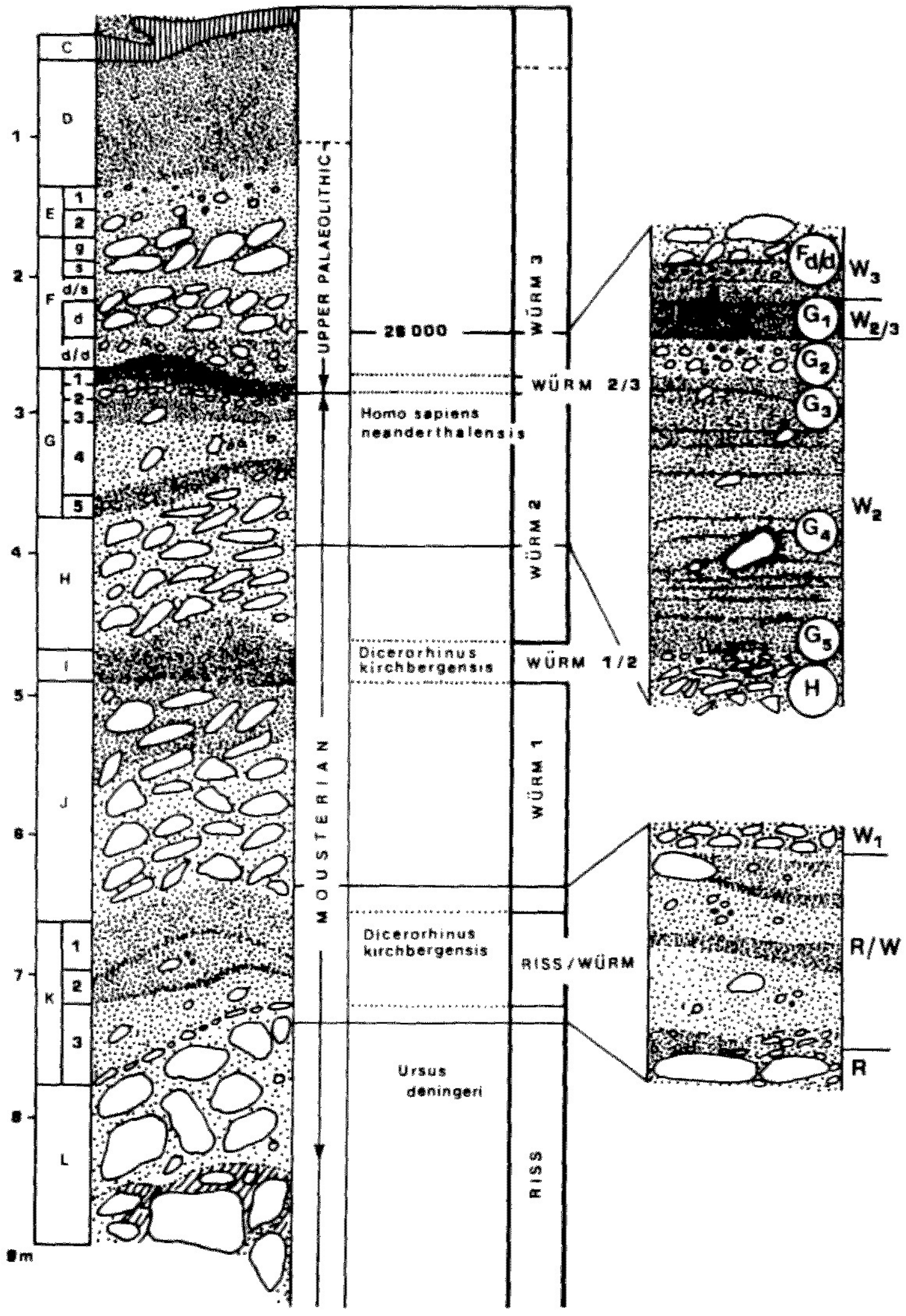

Figure 2. Stratigraphic Sequence of Vindija Cave (Rukavina 1983) 
Malez (1988), yielded an age of $26,970 \pm 632$ B.P. This is probably the same date originally

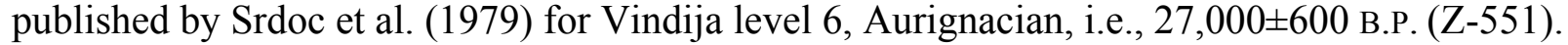

$\mathrm{Fd} / \mathrm{s}$ : an $8-\mathrm{cm}$-thick layer of mainly silty clay with no stone rubble. This level also includes a sandy lens underlying the clay and containing very little stone rubble.

Fs: sandy sediment with abundant rubble and large stone blocks.

Fg: sandy sediment with abundant small cryoclastic rubble.

Level E is gray sandy sediment, with abundant stone rubble. Thickness of this level does not exceed $60 \mathrm{~cm}$, and it occasionally pinches out because of cryoturbation processes. Radiocarbon dating of cave bear bones produced an age of 18,500 \pm 300 B.P. (Z-2447) (Obelic et al. 1994).

On the basis of the already mentioned modified subdivision scheme for the Pleistocene (Malez and Rukavina 1979), complex F and level E have been attributed to Wiirm 3.

Level D is gray-orange fine sandy sediment, $50-150 \mathrm{~cm}$ thick. It sedimented during a cold and dry period and has been attributed to the Late Glacial or end of Wurm 3 (Malez and Rukavina 1979:199).

\section{RAW MATERIALS}

The Paleolithic artifacts of Vindija Cave have been petrographically analyzed by D. Kurtanjek and V. Marci (1990). The groups of rocks used to produce the artifacts were determined by macroscopic analysis under low magnification. Overall, white quartz makes up $49.95 \%$ of the lithic artifacts; chert, 31.6\%; tuff, 13.25\%; sandstone, 3.1\%; and biotite-cordierite hornfels, $0.04 \%$, with $2.4 \%$ not determinable. The percentage of employed rocks varies considerably between the Upper and Middle Paleolithic assemblages. In the Middle Paleolithic, the rock most frequently used in producing tools was white quartz, which accounts for $55 \%$, followed by chert with less than 30\%. Chert prevails in the Upper Paleolithic levels, with more than 50\%, followed by white quartz with less than $30 \%$. All these rocks are found in the environs of the cave, and no item suggests any other sources of material (Kurtanjek and Marci 1990:235), meaning that the Vindija Upper Pleistocene hunters produced their tools by drawing on local raw materials. The types of raw materials used during the Aurignacian appear to be more limited than those of the various Gravettian phases, a characteristic of other Paleolithic sites in Croatia.

\section{STONE AND BONE INDUSTRY}

\section{Level Gl}

Gl is the first level which can reliably be attributed to the Upper Paleolithic. It contains 56 chipped stone items, of which $15(26.8 \%)$ are tools. This level contains 4 denticulated pieces (Figure 3, no. 1) and as many sidescrapers (Figure 3, no. 3). A leaf-shaped bifacial piece (Figure 3 , no. 4), like those found in the Szeletian, has also been recovered from this level. This piece (a point) 
is thin and very finely worked on both faces. Two endscrapers on flakes (Figure 3, no. 5), an endscraper on a retouched blade, a straight dihedral burin (Figure 3, no. 2), and a blade with two continuously retouched edges suggest an Upper Paleolithic technological attribution for the level. A hammerstone with visible damage due to striking has also been found. Bone tools are typical of the Aurignacian, particularly the split-base bone point (Figure 3, no. 7), as well as massive-base bone points (Figure 3, no. 6) and medial point fragments. The level also yielded a bear pubic bone with a carved circular decoration (Figure 3, no. 8) and a "bone button." The socalled bone buttons are probably only pieces of bone crushed by animals (Turk 1988:61-63) and not products of human activity. The cultural inventory may be attributed to the Aurignacian. If the occurrence of sidescrapers had not been caused by cryoturbation, it might suggest continuation of the Mousterian technological tradition. However, the quantity of tools is too small to allow for a firmer conclusion.

\section{GIF Interface}

Stone artifacts marked G/F, F/G, or Fd/G comprise 72 items found along the interface of the $\mathrm{G}$ and $\mathrm{F}$ complexes; in some cases, cryoturbation has eliminated the possibility of reliably establishing to which complex the artifacts might belong. The transition of complex $G$ to complex $\mathrm{F}$ is distinguished by Aurignacian assemblages. Tools account for 20 items (27.8\%). The inventory comprises 4 endscrapers (20\%): an atypical endscraper on a blade, an endscraper on an Aurignacian blade (Figure 4, no. 1), an atypical keeled endscraper, and a thick-nosed endscraper (Figure 4, no. 3). Three burins (15\%) are present: a straight dihedral burin, an angle burin on a blade, and a burin on an oblique retouched truncation. There are 8 retouched blades: 5 with two continuously retouched edges, 2 with one continuously retouched edge, and 1 Aurignacian blade (Figure 4, no. 2). The keeled endscraper, the flat-nosed endscraper, the endscraper on an Aurignacian blade, and the Aurignacian blade are all typical of the Aurignacian. Other tools present include a chopper.

\section{$F d / d+G l$ Interface}

This stratigraphic unit produced only five types of tools along the level interface, which is also the interface between complexes G and F. Despite the small sample, the Upper Paleolithic character of the double-ended endscraper (Figure 4, no. 4) and of the endscraper on a blade, the rabot, and the blade with one continuously retouched edge is obvious. A denticulated piece is also present, as well as bone points with massive bases (Figure 4, no. 5). The characteristics of these tools suggest an Aurignacian attribution.

\section{Complex F}

This designation includes 144 stone artifacts. Almost all of these artifacts are marked only with the designation of the complex, without a more detailed indication of level; the indication of the level was illegible in two items and 

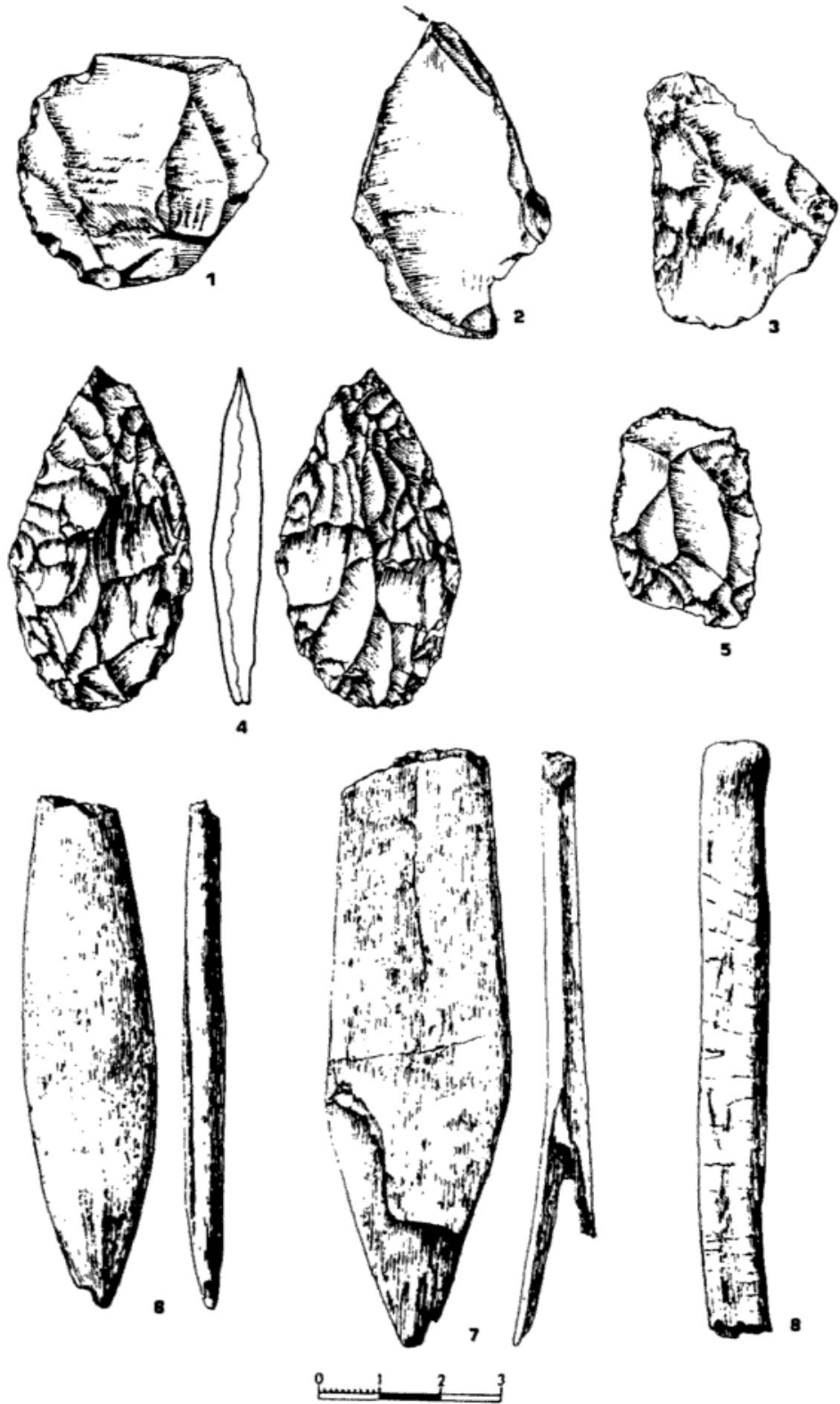

Figure 3. Selected Artifacts from Level Gl, Vindija Cave

1. denticulated piece

2. straight dihedral burin

3. sidescraper

4. leaf-shaped bifacial piece

5. endscraper on a flake
6. massive-base bone point

7. split-base bone point

8. bear pubic bone with carved circular decoration 
absent in one. When possible, the assemblage with level designation is analyzed separately in greater detail below. The chronological span of complex F is too large and the characteristics of the industries found between the bottom and top levels too different for statistical methods to produce a reliable result. Accordingly, no cumulative percentage curve has been drawn. Tools account for a total of 55 items $(38.2 \%$ of the overall inventory marked with F). The most numerous tools are notched pieces and endscrapers (10 in each category, 18.2\%); 3 endscrapers on retouched blades and as many endscrapers on flakes, the 2 thick-nosed endscrapers, and 1 atypical keeled and flat-nosed endscraper are typical of the Aurignacian. Out of the total of 9 blades $(16.4 \%), 5(9.1 \%)$ exhibit two continuously retouched edges, and $4(7.3 \%)$ show one continuously retouched edge. The inventory also includes 7 (12.5\%) side-scrapers and raclettes and $6(16.4 \%)$ denticulated pieces. A convergent side-scraper, rarely found in the Upper Paleolithic, is of particular interest. There are also 3 burins (5.5\%): a straight dihedral burin, a burin on an oblique retouched truncation, and a multiple mixed burin, along with 3 combined tools of the burin-truncated blade type. The F label is also found on a bone awl and on "bone buttons." Aurignacian type tools probably belong to the inventory of lower F-complex levels. A more precise conclusion is not possible, and a clearer picture has been obtained by the division of the complex into several levels. As mentioned above, the F complex was subsequently divided into several levels marked $\mathrm{Fd} / \mathrm{d}, \mathrm{Fd}, \mathrm{Fd} / \mathrm{s}, \mathrm{Fs}$, and $\mathrm{Fg}$. In order to obtain more relevant indices, their inventories have been classified separately in this study.

Level Fd/d

$\mathrm{Fd} / \mathrm{d}$ is the lowest level within complex F. It contains 89 stone artifacts, of which $30(33.7 \%)$ are retouched tools. Most numerous are 9 denticulated pieces (30\%; Figure 4, no. 8), followed by 5 notched pieces and 5 burins (16.7\%): 2 nucleiform burins, 1 multiple dihedral burin, 1 burin on an oblique retouched truncation, and 1 nosed burin. The inventory includes $4(13.3 \%)$ sidescrapers and as many blades with one or two continuously retouched edges. The nosed burin is typical of the Aurignacian. The level also yielded 2 blades with an oblique retouched truncation (Figure 4, no. 9), typical of the Gravettian and indicative of probable mixing of the Gravettian and the Aurignacian in the level. These two finds do not warrant a reliable classification of this assemblage into the Gravettian because of the several Aurignacian types found in complex $F$ which probably belonged to the bottom level $(\mathrm{Fd} / \mathrm{d})$ of the complex. 

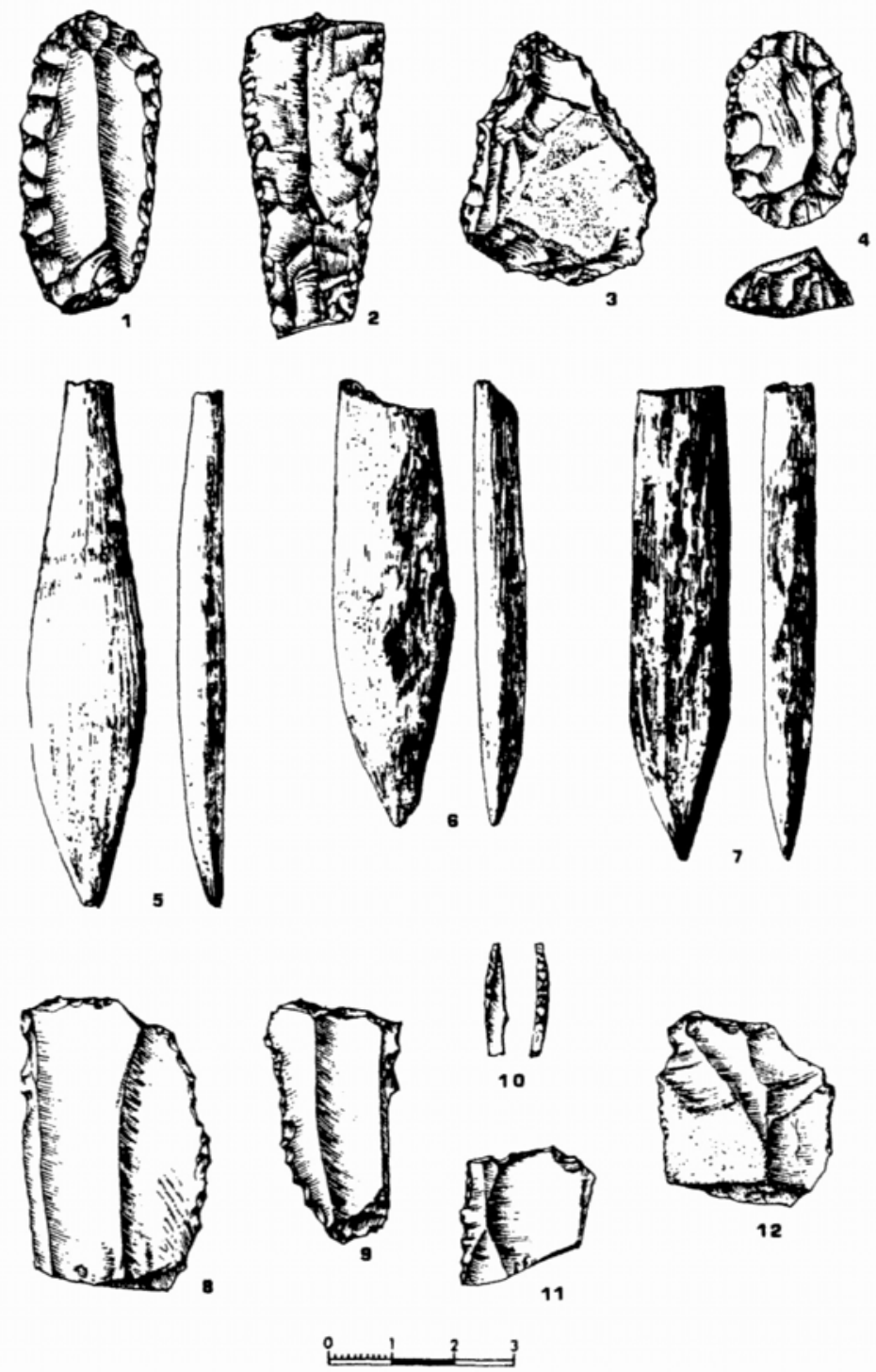

Figure 4. Selected Tools from Vindija Cave

Border of Complex F and Complex G:

1. endscrapcr on an Aurignacian blade

2. Aurignarian blade

3. flat-nosed endscraper

4. double-ended endscraper

5. massive-base bone point
Level Fd/d:

6-7. massive-base bone points

8. denticulated piece

9. blade with an oblique retouched truncation Level $\mathrm{Fd} / \mathrm{s}$ :

10. backed bladelet

11. blade with oblique retouched truncation 12.raclette 
Bone tools found in the level include 2 bone points with massive bases and broken distal ends (Figure 4, nos. 6, 7), all suggesting an Aurignacian attribution.

\section{Level Fd}

The 147 stone artifacts found in the level cannot be defined reliably. Tools account for 28 (19\%) of these items. The inventory includes 5 denticulated pieces $(17.9 \%)$ and 5 sidescrapers; there are 4 burins (14.3\%), each of a different type (dihedral angle burin, multiple mixed burin, nucleiform burin, flat-faced burin). A combined tool (burin-truncated blade) has also been found. One of the tools was produced from an originally Mousterian core. A chopping tool was also found in the same level. Bone tools include several medial point fragments. The industry cannot be determined reliably.

\section{Level Fd/s}

$\mathrm{Fd} / \mathrm{s}$ is the oldest level which, in spite of the small number of tools, can be defined as Gravettian with a fair degree of reliability. The inventory of level $\mathrm{Fd} / \mathrm{s}$ includes 89 stone artifacts, out of which 15 are tools (16.9\%). The 4 denticulated pieces account for $26.7 \%$ of the tool assemblage. The 3 raclettes $(20 \%)$ differ from the same tool type in Western Europe, where this tool is often found in the early Magdalenian. The raclettes found in Vindija are rougher and often more robust, but they may be included in this type on grounds of general morphological similarity and the frequently short retouching of the edges (Figure 4, no. 12). Other tools include 2 blades with two continuously retouched edges and 1 blade with an oblique retouched truncation (Figure 4, no. 11), the latter characteristic of the Gravettian. A backed bladelet (Figure 4, no. 10) found in this deposit is also typical of the same techno-complex. Bone artifacts found in this level include a fragment of a point or, perhaps, of an awl with a broken tip and an intact proximal end. Chronostratigraphy considerations tend to confirm an attribution to the Gravettian.

\section{Level Fs}

Out of the 18 stone artifacts, $5(27.8 \%)$ belong to definable tool types (rabot, blade with one continuously retouched edge, denticulated piece, scraper). Bone artifacts found in the level comprise a point base and 3 medial fragments. The stone artifacts can be attributed to the Gravettian or maybe Late Gravettian only on the basis of the chronostratigraphic position of the deposit. 


\section{Level Fg}

Only 4 tools (blade with two continuously retouched edges, notched piece, 2 scrapers) and 1 flake carry the designation of this level. In chronostratigraphic terms, the artifacts can be attributed to the Gravettian or Late Gravettian.

\section{E/F or $E+F$ Interface}

The designation $\mathrm{E} / \mathrm{F}$ or $\mathrm{E}+\mathrm{F}$ is found on 204 stone artifacts excavated along the interface between complex $\mathrm{F}$ and level $\mathrm{E}$; in some cases, they could not be reliably attributed to a specific level because of cryoturbation. Twenty items $(9.8 \%)$ can be classified in terms of tool type. The 6 sidescrapers account for as much as $30 \%$ of the tool assemblage, this tool type being otherwise typical of the Middle Paleolithic. The inventory also includes 6 burins ( 3 dihedral angle burins, 2 straight dihedral burins, and 1 nucleiform burin) and a combined tool (a scraperburin). Bone tools include 2 fragments of massive-base points (one flat and one round) and a circular section fragment. These points resemble Aurignacian artifacts, although, according to Albrecht, Hahn, and Torke (1972:81), they can also be attributed to the Gravettian. There are no typical Aurignacian stone tools, a fact which warrants the conclusion that these stone industry items belong to the Upper Gravettian levels of complex F or to the Late Gravettian level E.

\section{Level E}

Level $\mathrm{E}$ belongs to the later Gravettian phase. It yielded 49 stone artifacts. Nineteen of these (38.8\%) could be classified as formal tools. The 5 burins, accounting for $26.3 \%$ of the stone tool assemblage, include 3 multiple mixed burins and 2 angle burins on a blade (Figure 5, no. 3). There are also 5 sidescrapers, 2 notched pieces (10.5\%), 2 notched bladelets (Figure 5, nos. 2, 5), and 2 endscrapers (an endscraper on a blade [Figure 5, no. 1] and an atypical keeled endscraper). Although level $\mathrm{E}$ is more recent than the Aurignacian, it yielded a keeled endscraper characteristic of the Aurignacian. Such tools may have been present in the Gravettian, but they may also have been driven up from lower (Aurignacian) levels by cryoturbation processes. Bone tools include an awl, a point or awl fragment, and a "bone button." The material culture of level E should be attributed to the Late Gravettian, consonant with the chronostratigraphic position of the deposit and its ${ }^{\mathrm{H}} \mathrm{C}$ date. 

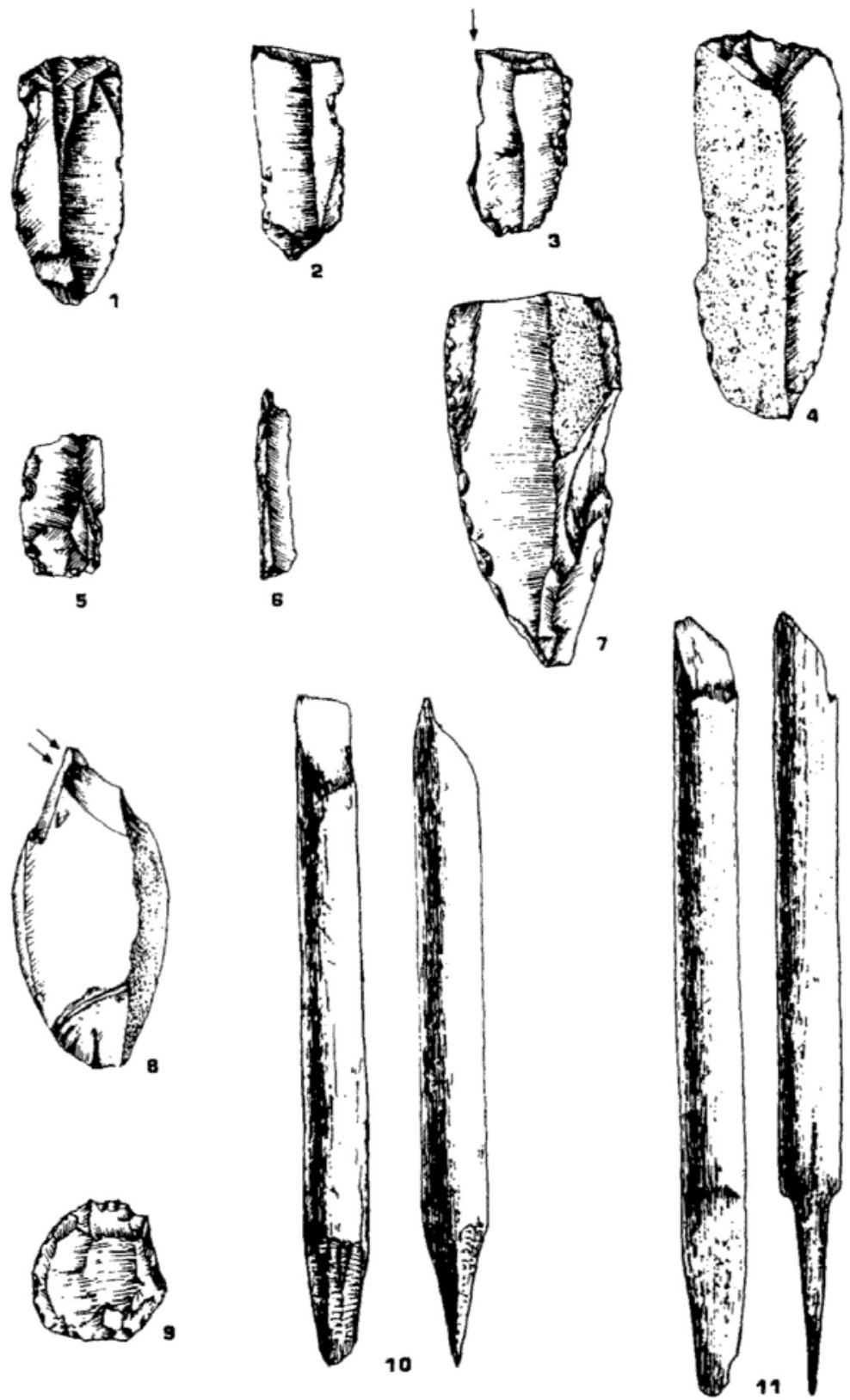

Figure 5. Selected Tools from Vindija Cave

Level E:

1. endscraper on a blade $2 \& 5$. notched bladelets

3. angle burin on a blade

8. straight dihedral burin

9. circular endscraper
Level D:

4. endscraper on a blade

6. microdrill

7. blade with two continuously retouched edges

$10 \& 11$. sagaie fragments 


\section{$D+E$ Interface}

Seventeen knapped-stone items bear the designation D+E. Either they had been found along the interface of these levels or, because of disturbance, their position could not be defined accurately. Eight items can be classified as tools (47.1\%). All the types are typical of the Upper Paleolithic, while the blade with oblique retouched truncation is typical of the Gravettian. Most of the tools are burins ( 2 multiple dihedral burins and 1 straight dihedral burin).

\section{Levels $D$ and D-Up}

Level D represents the final stage of the Gravettian, while the designation D-Up is found on several bone artifacts and pottery fragments. Out of the 94 stone artifacts foimd in level D, 45 $(47.9 \%)$ are tools. Most of these are blades (16 pieces, 35.6\%): 7 with one continuously retouched edge, 6 with two continuously retouched edges (Figure 5, no. 7), 2 with a convex retouched truncation, and 1 with a straight retouched truncation. A combined tool (endscrapertruncated blade) has also been found. The 8 burins (17.8\%) belong to seven different types: 2 straight dihedral burins (Figure 5, no. 8), 1 canted dihedral burin, 1 dihedral angle burin, 1 angle burin on a blade, 1 multiple dihedral burin, 1 burin on a concave retouched truncation, and 1 multiple mixed burin. The following tools found in the level under consideration are typical of the Gravettian: 2 blades with convex retouched truncation, 1 blade with straight retouched truncation, and 1 shouldered piece. A circular endscraper (Figure 5, no. 9) and a microdrill (Figure 5, no. 6) with pronounced microlithization appear for the first time in the inventory of Vindija levels. There is also an endscraper on a blade (Figure 5, no. 4) and an endscraper on a retouched blade. Bone tools include circular section sagaie fragments (Figure 5, nos. 10, 11). Such types are found in the Franco-Cantabrian Magdalenian, which is, nonetheless, not present in Croatia. Tools marked D belong to the end of the Upper Paleolithic, i.e., to the final Gravettian phase, probably the Epigravettian. There are no characteristic Mesolithic industry types. Of all the Upper Paleolithic Vindija levels, this level contains the largest number of stone tools. Accordingly, the relative frequencies of stone tool types are presented in Table 1, in a cumulative percentage graph (Figure 6), and by tool group histograms (Figure 7). However, it should be noted that the assemblage still totals less than 100 stnnp tnrJc than 100 stone tools.

The designation D-Up is found on 2 spearlike fragments, 2 awls, and a pendant made from a boar incisor. It has not been possible to determine whether these tools belong to the same culture as those marked D or to a later culture. Fragments of Eneolithic and early Bronze Age pottery also bear the indication D-Up.

It should be noted that Vukovic (1961) published an analysis of Vindija stone artifacts, among which are several items typical of the Mesolithic. They were found in deposit II (Vukovic 1961:11, 12), the equivalent of which can not readily be found in the stratigraphy of Malez and Rukavina (1979). 


\section{TABLE 1 Numbers and Percentages of Stone Tool Types in Level D, Vindija Cave}

\begin{tabular}{lll}
\hline Tool Type & Number & Percentage \\
\hline 1 Endscraper on a blade & 1 & 2.22 \\
5 Endscraper on a retouched blade & 1 & 2.22 \\
9 Circular endscraper & 1 & 2.22 \\
18 Endscraper on a truncated blade & 1 & 2.22 \\
26 Microdrill & 1 & 2.22 \\
27 Straight dihedral burin & 2 & 4.44 \\
28 Canted dihedral burin & 1 & 2.22 \\
29 Dihedral angle burin & 1 & 2.22 \\
30 Angle burin on a blade & 1 & 2.22 \\
31 Multiple dihedral burin & 1 & 2.22 \\
36 Burin on a concave retouched truncation & 1 & 2.22 \\
41 Multiple mixed burin & 1 & 2.22 \\
57 Shouldered piece & 1 & 2.22 \\
60 Blade with straight retouched truncation & 1 & 2.22 \\
63 Blade with convex retouched truncation & 2 & 4.44 \\
65 Blade with one continuously retouched edge & 7 & 15.56 \\
66 Blade with two continuously retouched edges & 6 & 13.33 \\
74 Notched piece & 6 & 13.33 \\
75 Denticulated piece & 3 & 6.67 \\
78 Raclette & 4 & 8.89 \\
89 Notched bladelet & 2 & 4.44 \\
Totals & 45 & 100.00
\end{tabular}

\section{OVERVIEW OF THE VINDIJA UPPER PALEOLITHIC}

According to Malez and Rukavina (1979), the stratigraphic complex of Vindija Cave (see Figure 2, above) spans a continuous time sequence from the Riss glaciation to the Holocene. It includes Paleolithic (Mousterian, Aurignacian, Gravettian, Late Gravettian, and final Gravettian/Epigravettian), Neolithic, Eneolithic, Bronze Age, and Roman levels. Because of the relatively small number of tools found in the Vindija Upper Paleolithic levels, and because of stratigraphic disturbances due to cryoturbation, it has not been possible to obtain a sufficient amount of relevant data for producing a graphic representation of the relative frequencies of tools. This has been attempted only in level D; here the number of stone tools is somewhat larger (45 pieces), but it is still insufficient for a fully conclusive diagnosis.

The relatively small quantities of tools found in individual stratigraphic levels and the absence of hearths or even significant concentrations of ashes suggest that Vindija Cave was inhabited in relatively short, although frequent, episodes during the Upper Paleolithic.

Although the analysis covered all the Upper Paleolithic lithics kept in the Institute for Paleontology and Quaternary Geology in Zagreb, the amount of 


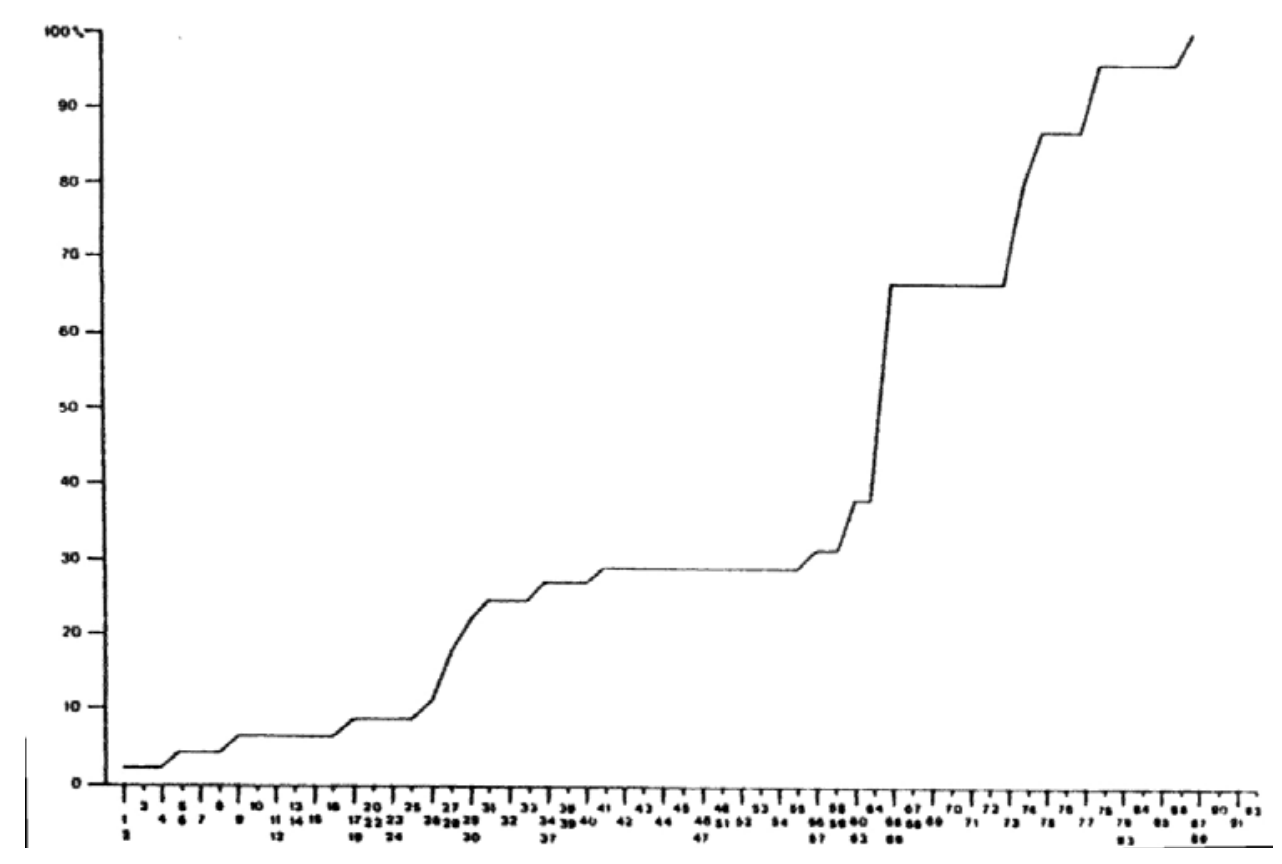

Figure 6. Cumulative Percentage Graph of Stone Tool Types in Level D, Vindija Cave

Horizontal axis lists artifact types according to the numerical arrangement of Sonneville-Bordes and Perrot (1953). See Table 1 for names of artifact types present in level I), Vindija Cave.

debitage is unusually low. Debitage makes up usually between $60 \%$ and $80 \%$ of the whole lithic assemblage in Vindija levels, but in some levels (Fg, D) that percentage is considerably lower. Decortication material, which suggests in situ core preparation in the individual levels, varies between $4 \%$ and $15 \%$ of the debitage. However, the number of cores is very low: level G/F, 2 cores; F, 2 cores; Fd/d, 1 core; Fd, 3 cores and 1 Mousterian core transformed into a tool; and $\mathrm{Fd} / \mathrm{s}, 1$ core. All cores, except three bladelet cores marked as $\mathrm{G} / \mathrm{F}, \mathrm{Fd} / \mathrm{d}$, and $\mathrm{Fd} / \mathrm{s}$, are flake cores. Seven items marked as E/F or E+F could be either cores or chunks. It is impossible to be more precise because they are made of white quartz.

The analysis of the debitage shows that flake technique is far more usual than blade technique, which is very rare: less than 5\% in almost all levels. The exception is Epigravettian level D, where blades are $16.3 \%$ of the debitage, bladelets are $10.2 \%$, and $35.6 \%$ of the tools are retouched or truncated blades. The small number of cores and the low occurrence of debitage suggest that most of the tools were made outside the cave or that they had been brought from other sites. However, this conclusion is tentative because of the excavation methods; careful digging, dry screening, and water screening were applied on only a very limited part of the sediment. So, although all observed artifacts were collected, we can presume the loss of smaller finds. It should be 


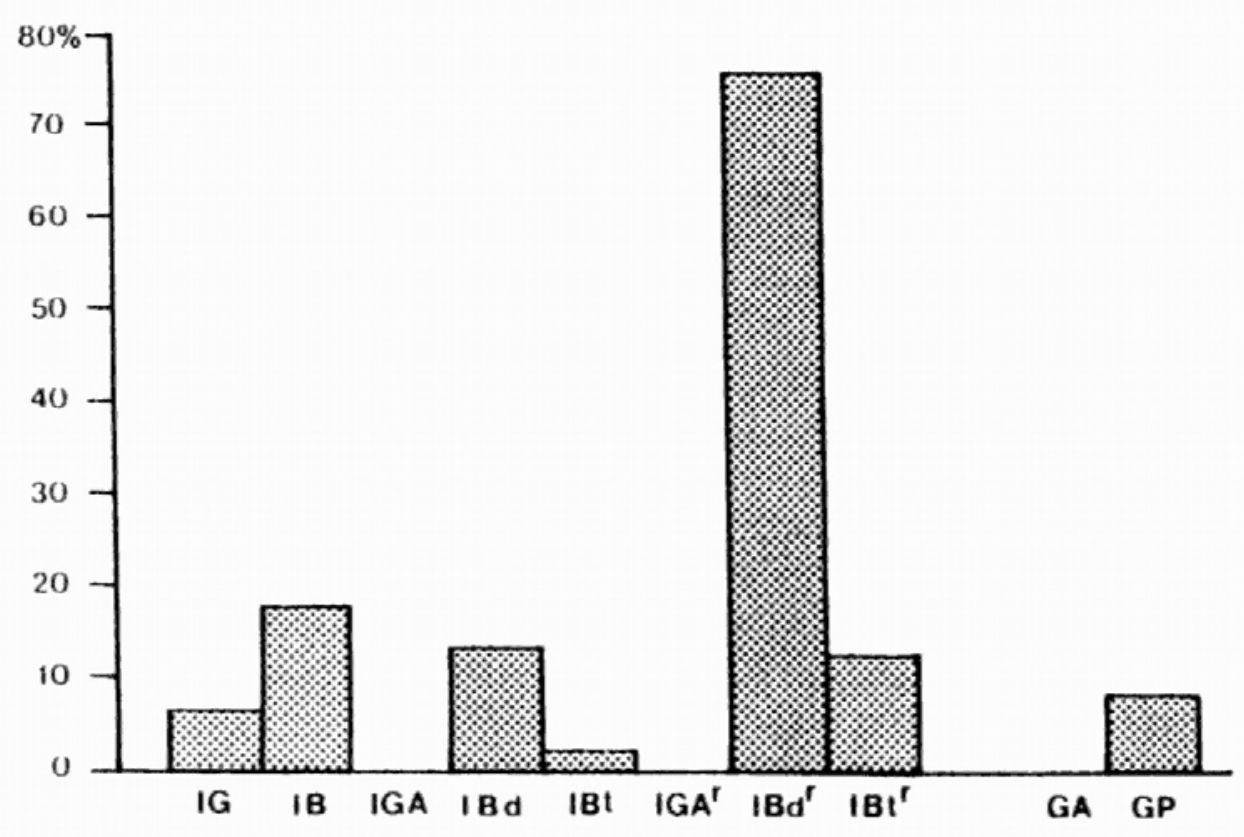

Figure 7. Stone Tool Group Histogram for Level D, Vindija Cave

Index abbreviations are as follows:

IG = Endscraper Index (percentage of $\quad$ GP $=$ Perigordian (Gravettian) Tool Group whole tool assemblage

$\mathrm{IB}=$ Burin Index

IGA $=$ Aurignacian Endscraper Index

$\mathrm{IBd}=$ Dihedral Burin Index

$\mathrm{IBt}=$ Truncation Burin Index Index

$\mathrm{IGA}^{\mathrm{r}}=$ Restricted Aurignacian Tool Group

$\mathrm{IBd}^{\mathrm{r}}=$ Restricted Dihedral Burin Index (percentage of burin group only)

$\mathrm{IBt}^{\mathrm{r}}=$ Restricted Truncation Burin Index

mentioned that the author of this paper was not present at the Vindija excavations and that information on excavation methods was given to me by members of Malez's research team. Vindija level Gl is the earliest level which can reliably be attributed to the Upper Paleolithic. Mousterian stone tool types such as sidescrapers, but also tools displaying Upper Paleolithic traits, are present. A bone point with a split base, typical of the Aurignacian, and bone points with massive bases are of particular significance. Therefore, the material culture is considered to belong to the Aurignacian. The leaf-shaped stone point should also be attributed to the Aurignacian, while similar points found in older G complex levels are to be attributed to the Mousterian. Despite a very few leaf-shaped points, Vindija cannot be attributed to the Szeletian as Malez (1975:140, 1988:21) has done. It ought to be noted that the Kamen site (Figure 1, no. 15) in Bosnia has also yielded bilaterally retouched points which can be attributed to the Late Mousterian or Aurignacian (Easier 1979a:333, 336).

Fossil human remains have been found close to the split-base point in Vindija level Gl. This part of the level wasnot disturbed by cryoturbation (J. Radovcic, personal communication). Along with traits typical of modern man, the fossils also display some morphological characteristics of late Neanderthal man. Un- 
less the few stone artifacts were mixed by cryoturbation with artifacts from underlying layers, their characteristics and the fossil human remains (Wolpoff et al. 1981) might suggest a continuous transition from the Middle Paleolithic to the Upper Paleolithic at this site. It could be argued (Stringer 1982a, 1982b) that the association of the Middle Paleolithic and the Upper Paleolithic stone tool types, as well as the fossil hominids, with the Upper Paleolithic bone industry could be caused by cryoturbation disturbances described by Malez and Rukavina (1975). However, as I mentioned before, certain parts of the cave (the left half) show undisturbed sjtratigraphic layering, so the association of the possible Neanderthals with Aurignacian bone tools cannot be explained by geological processes or by human activity. Furthermore, microscope analysis has confirmed that fine particles of distinctively colored redbrown sediment characteristic of level Gl have infiltrated the remains of the hominids and the bone tools, thus proving their contemporaneity - they belong to the same chronostratigraphic level, now dated to $33,000 \pm 400$ B.P.

Several Aurignacian tool types are marked only with the designation of strati-graphic complex $\mathrm{F}$, and the original levels within the complex cannot be distinguished among the artifacts. Most of them probably originate from the lowest level $(\mathrm{Fd} / \mathrm{d})$ of complex $\mathrm{F}$. Bearing this fact in mind, as well as the presence of Gravettian types, the industrial affiliation of levels $\mathrm{Fd} / \mathrm{d}$ and $\mathrm{Fd}$ cannot be determined reliably. Radiocarbon dating produced an age of $26,600 \pm 900$ B.P. for level $\mathrm{Fd} / \mathrm{d}$ and $26,970 \pm 632$ B.P. for level Fd. These dates are very young for the Aurignacian compared to other Central European sites (see Smith 1982: Table 1), suggesting either that basal complex F is at the end of the Aurignacian in this area or a possible error in dating procedure (or in the collection of specimens), while the presence of Gravettian types (two blades with retouched truncation) in level $\mathrm{Fd} / \mathrm{d}$ might suggest some mixing of Aurignacian and Gravettian materials in that deposit. Because of the relatively small number of typical tools bearing the $\mathrm{F}$ complex designation, a more definitive conclusion is not possible at the present time.

\section{COMPARISONS WITH SOME CENTRAL EUROPEAN AND BALKAN SITES}

Vindija Aurignacian bone points resemble the points found in Velika Pecina (Malez 1967). Level i of Velika Pecina (Figure 1, no. 2) yielded three split-base points, and level h, a fragment of a split-base bone point; bone points have also been found in levels $g$ and $\mathrm{f}$. These points belong to the Aurignacian (Malez 1974:Fig. 1). Radiocarbon dating for the Aurignacian in Velika Pecina yielded 33,850+520 B.P. (GrN-4979) for level i (Malez and Vogel 1970) and 27,300 1200 B.P. (Z-189) for level g (Srdoc et al. 1973). The first date is older than those obtained for levels $\mathrm{Fd} / \mathrm{d}$ and $\mathrm{Fd}$ in Vindija and matches Vindija level Gl, now dated to $33,000 \pm 400$ B.P. (ETH-12714). Equivalents of Vindija and Velika Pecina bone points have been found at 
MokriSka Jama (Figure 1, no. 8) and Potocka Zijalka (Figure 1, no. 6), Alpine Paleolithic sites in Slovenia (Brodar and Osole 1979), and at many Central European sites (Albrecht, Hahn, and Torke 1972). At Potocka Zijalka, only one split-base point has been found among massive-base points. Two point types (a large split and a massive-base one) have been found together at MokriSka Jama, which indicates their co-occurrence. Thus, the division of the Aurignacian at Vindija (Malez 1988:221) into "Aurignacian I" (with split-base points) and "Aurignacian II" (with massive-base points) becomes meaningless. Only massive-base points occur later both at Vindija and at MokriSka Jama, showing that split-base points went out of use earlier. MokriSka Jama points are distinguished by an oval-flat section, like the Aurignacian specimens found at Vindija and Velika Pecina, while Potocka Zijalka points are mainly thick and oval.

No bone artifacts have been found at Aurignacian sites in the northern Bosnian belt, and the closest analogies to these sites are found at a number of localities in other parts of the Pannonian region - in the environs of VrSac, the Romanian part of Banat and Slavonia (Basler 1979a:341). According to Easier, a "progressive" Aurignacian probably had already appeared in the Pannonian region in the initial phases of the Upper Paleolithic; however, the absence of bone artifacts and the rather small quantity of stone tools make it difficult to compare this region to the area under consideration in this paper.

In terms of Aurignacian stone and bone industries (Valoch 1968; Albrecht, Hahn, and Torke 1972), the Aurignacian at Vindija resembles many sites in the eastern part of Central Europe, but Vindija's Aurignacian cannot be reliably divided into stages because of the insufficient number of finds and disturbance of stratigraphic units. In view of its large number of archaic Mousterian types, Vindija's level Gl could possibly be attributed to this lower stage, which is also present at the sites of Malomerice-Obciny and Krepice in Moravia and Barca II in eastern Slovakia (Valoch 1968).

Level Fd/s is the first Vindija level which can reliably be attributed to the Gravettian. It also occurs in levels Fs, Fg, and, in its late stage, in level E. These levels of the F complex contain relatively few stone tools, which include Gravettian types, while most bone tools are not uniquely typical of one industry. On the basis of bone artifacts, Malez (1988) attributed Vindija levels Fg and E to "Aurignacian II," which does not correspond to the characteristics of the stone tools found in these levels or to the ${ }^{14} \mathrm{C}$ date of $18,500 \pm 300$ B.P. for level E (Obelic et al. 1994).

Gravettian material was found at Velika Pecina in level e, and, in view of a ${ }^{\mathrm{M}} \mathrm{C}$ date of 26,450 \pm 300 B.P. (GrN-4980) (Malez and Vogel 1970), as well as the chronostratigraphy and industry, this level could correspond to Vindija level Fd/s, while Vindija levels Fs, Fg, and E are of more recent date.

At Slovenian sites, Parska Golobina (Figure 1, no. 12), Betalov Spodmol (Figure 1, no. 9), and Spehovka (Figure 1, no. 7), the presence of Gravettian assemblages has been established in the most recent levels (Brodar and Osole 1979). The inventory excavated at Parska Golobina includes a backed bladelet, 
and two such types have been found in the area in front of Spehovka Cave (Brodar and Osole 1979). A backed bladelet was found in the Gravettian Fd/s level at Vindija, but it is somewhat smaller (with more pronounced micro-lithization) than the bladelets found at Spehovka. The Gravettian at Betalov Spodmol (Osole 1991), just like Late Gravettian level E at Vindija, has yielded Aurignacian tool types. Two keeled endscrapers and two atypical keeled end-scrapers have been found in culture horizon $\mathrm{F}$ at Betalov Spodmol, while one endscraper on a blade and one atypical keeled endscraper have been excavated in Vindija level E. These would suggest a lack of absolute exclusivity of keeled endscrapers in the Aurignacian.

The Gravettian of the Kadar site (Figure 1, no. 14) in Bosnia displays similarities with the Gravettian of the greater Pannonian region (Easier 1979a:344), while differing from Vindija in terms of the incidence of specific tool types. Thus, whereas many backed bladelets have been excavated at Kadar, the Vindija inventory contains only one specimen. Unlike Kadar, Vindija yielded no fan-shaped endscrapers. However, the industry at Kadar belongs to the late, rather than the early, phase of the Gravettian (or Epigravettian) (Montet-White, Laville, and Lezine 1986) and is possibly contemporary with Vindija's Late Gravettian. The scarcity of backed bladelets in the Vindija Gravettian levels may be due to methodological problems during excavation.

As already mentioned, the industry of level E at Vindija belongs to a late Gravettian phase. In terms of age, it corresponds to the "Tardigravettian" of Slovenia, which in turn shows considerable similarities with the West European Gravettian, from which it most probably developed (Brodar and Osole 1979). Sites included in this group could also be called reindeerhunting stations, because bones of reindeer prevail over other fauna in most of them (e.g., Jama v Lozi, Ovcja Jama, Ciganska Jama) (Brodar and Osole 1979). The Tardigravettian of Jama v Lozi is distinguished by the large number of burins (Brodar and Osole 1979); this trend is present in the Vindija Gravettian, particularly in the Epigravettian levels. The cultural inventory of Ovcja Jama (Figure 1, no. 11) is distinguished by significant microlithization (Pohar 1978), which is not so much the case at Vindija. Resemblances may be noted between several types of stone tools from the Vindija Gravettian and Late Gravettian levels and those from the upper cultural level at Ciganska Jama (Figure 1, no. 13), attributed to the developed Gravettian (Brodar 1991:23); however, as noted above, Vindija has yielded one backed bladelet, a type which, in contrast, abounds at the Slovenian site.

The difference between the Late Gravettian at Vindija and the Pavlovian in Moravia is evidenced by the absence at Vindija of specific tool types (e.g., micro-saws found at Dolnf Vestonice or small geometric forms recovered at the Pavlov site [Valoch 1968]) and primarily by the absence of the archetypical Gravettian tool-the Gravette point - in the Vindija inventory.

Vindija level D is a continuation of the Late Gravettian and represents another, final ("Epi-") phase of the Gravettian. In terms of age, it matches the 
Epigravettian of Slovenian sites. The stone artifacts of level D at Vindija are distinguished by a fairly high percentage of blades and burins (and notably a circular endscraper), while "Magdalenian-like" sagaies prevail among the bone tools. A petrographic analysis (Kurtanjek and Marci 1990) has demonstrated the local character of the Vindija raw materials. However, the equal quantities of tools and debitage in level D suggest that some of the tools may have been produced outside the cave area or that some types may have been transported from other sites.

The Epigravettian (Brodar and Osole 1979; Osole 1976, 1983) of Zupanov Spodmol (Figure 1, no. 10), Lukenjska Jama, and Babja Jama (Figure 1, no. 5) could be contemporary with the Vindija Epigravettian. However, in terms of tool types, there is no particular similarity between Lukenjska Jama or Babja Jama and Vindija level D.

As already mentioned, the Vindija Late Gravettian is synchronous with the Slovenian Tardigravettian, and the Vindija Epigravettian with the Epigravettian of Slovenia. However, in Slovenia the division into Tardigravettian and Epigravettian is mainly based on fauna. In numerical terms, the Slovenian Tardigravettian is distinguished by the prevalence of reindeer (Rangifer tarandus); Epigravettian fauna still includes ice-age elements (Rangifer tarandus), though these were being driven out by representatives of milder climate faunas such as moose (Alces alces) and, later, red deer (Cervus elaphus). The Alpine marmot (Marmota mannota) was present up to the Holocene (Brodar and Osole 1979:180). The different Gravettian levels of Vindija contain too few artifacts for meaningful assignment to specific phases, and the fauna has not yet been analyzed comprehensively.

There are notable differences between the Upper Paleolithic at Vindija and at sites along the Adriatic coast, e.g., Sandalja II (Figure 1, no. 18) in Istria (southwestern Croatia) near Pula. The Aurignacian, several Gravettian phases, and the Epipaleolithic have been described at the latter site (Malez 1987). Stone artifacts are much more abundant compared with the Upper Paleolithic levels at Vindija. The raw materials at Sandalja include chert (about 96\%) and tuffs (Zupanic 1975), while other rocks, also of lower quality, were also used for the Vindija artifacts (Kurtanjek and Marci 1990). No split or massive-base points have been found in the Sandalja II bone inventory.

The site of Badanj (Figure 1, no. 16) near Stolac in Herzegovina belongs to the AdriaticMediterranean region. It is distinguished by Late Epigravettian artifacts, with a considerable increase in small circular endscrapers late in the sequence (Easier 1976, 1979a). The incidence of endscrapers is very high, while the percentage of burins is very low (Easier 1979a). These characteristics depart considerably from Vindija Epigravettian level D, where many burins, but only one circular endscraper, have been found.

Levels X-V at Crvena Stijena (Figure 1, no. 17) in Montenegro contain Upper Paleolithic material cultures (Easier 1979b). This locality also belongs to the Adriatic-Mediterranean region. Level $\mathrm{X}$, attributed conditionally to the 
Aurignacian, does not, however, contain typical Aurignacian tools. This may be a feature specific to the Adriatic-Mediterranean region (Basler 1979b). Levels IX and VIII contain a Late Epigravettian assemblage, while levels VII-V can generally be attributed to the Epipaleolithic. There are possible parallels between Crvena Stijena and Badanj and the Apulian sites. But there are no great similarities between these cultures and Western or Central European sites, the latter of which include Vindija and Velika Pecina.

\section{VINDIJA FAUNA AND HOMINIDS}

The fauna from Vindija has been only preliminarily analyzed so far (Malez and Rukavina 1979). The results of a revision of the fauna suggest some changes in the published species determinations: i.e., the absence of Saiga tatarica and the slight presence of Rangifer tarandus (D. Brajkovic, personal communication). Therefore, we could conclude that representatives of distinctive cold climate elements are relatively rare. It seems that there is no significant difference between the fauna of the Aurignacian and Gravettian, and it is impossible to draw a more precise conclusion, due to defective labeling of most of the material. Just as with the stone industry, on many bones only the strati-graphic complex is indicated, without precise level marking. This makes the establishment of a reliable correlation between industry and fauna impossible. Part of the faunal material has marks made by defleshing and by burning. The most frequent cut-marks have been found in Epigravettian level I): on approximately 18\% of the determinate ungulate material thus far analyzed. The stone industry of that level (with a large quantity of blades) suggests butchering. More relevant data will probably be available after thorough analysis of the faunal material is completed.

However, it is the hominid finds of Vindija and their association with industries of the Middle and Upper Paleolithic that pose the most interesting and puzzling problems of this site. The fossil remains can be stratigraphically separated into three groups (Smith 1982:634; Smith and Ahern 1994). The first group consists of remains of Neanderthal from level G3 in association with the late Mousterian. The second one consists of hominid remains from level Gl (right ramus and posterior mandibular corpus, teeth, anterior superior fragment of left parietal, zygomatic, supraorbital torus) in association with Aurignacian, three isolated teeth from Aurignacian level $\mathrm{Kd}$, and a posterior fragment of left parietal from the contact of Aurignacian levels $\mathrm{Fd}$ and $\mathrm{Fd} / \mathrm{d}$. The third group comprises finds of Homo sapiens sapiens from Epigravettian level D. The first two groups will be discussed in more detail.

Smith (1982:676) clearly indicates the importance of the hominid remains from level G3: "The Vindija G3 Neanderthals as a group give clear indications of morphological change in the direction of what is characteristic for early modern $H$. sapiens in this region." That evolutionary trend is also observable in the finds from level Gl. The mandible found near the split-base point is 
especially interesting: "The dimensions of the corpus and the height of the ramus indicate that Vi 207 is a small specimen compared with the Neanderthals. The ramus height is lower than the four adult Krapina specimens preserving this region. It lays 2.9 standard deviations below their main value of $61.5 \mathrm{~mm}$ for ramus height measured from the base (Table 4). The ramus is the approximate size of the Tabun female" (Wolpoff et al. 1981:511). Smith and Ahern (1994:279) describe the level Gl zygomatic and supraorbital fragments as coming from Neandertals. The posterior fragment of left parietal at lambda (from the contact between levels $\mathrm{Fd} / \mathrm{d}$ and $\mathrm{Fd}$ ) belongs more probably to Homo sapiens sapiens than to Neanderthal (Smith, Boyd, and Malez 1985), as corresponds to the absolute dating and to a probably Late Aurignacian industry in these levels. However, the three isolated teeth of possible Neanderthal morphology found in level Fd are debatable. Considering the late dating of level $\mathrm{Fd}$, a possible explanation could be that these teeth were pushed up by geological processes from lower, older levels. However, the fossil homi-nids found in association with Aurignacian materials in levels Gl and Fd are not significantly different from those associated with Mousterian materials elsewhere and provide a record of the evolutionary trend from Neanderthals to modern populations that came after them (Wolpoff et al. 1981). Therefore, Vindija is a most important archaeological, paleoanthropological, and paleon-tological site, with evidence for possible association of late Neanderthals with an early Upper Paleolithic Aurignacian industry. Based on the dates for Vindija level Gl (33,0()() $\pm 400 \mathrm{iu}>$.) and Velika Pecina level i $(33,850 \pm 520$ B.P.), with remains of Neandertals in the former and remains of early modern humans in the latter, there seems to be evidence for the contemporaneity of both subspecies in northwestern Croatia during the Aurignacian period.

\section{CONCLUSIONS}

The Upper Paleolithic industries of the Vindija site and their chronological framework have been discussed and compared with some contemporaneous Central European and Balkan sites on the basis of analyses of stone and bone tool types and results of ${ }^{\mathrm{H}} \mathrm{C}$ dating. In many levels at Vindija, the small number of tools and evidence of cryoturbation have made it impossible to arrive at definitive conclusions. Therefore, a completely reliable picture is still not possible, and more questions can be raised. Such questions may be summed up as follows: Was the transition from the Middle to the Upper Paleolithic at Vindija direct, and to which form of fossil human should it be attributed? Were the Middle and Upper Paleolithic tool types in level Gl produced by the same or by different cultural and anatomic groups of humans, or were Middle Paleolithic tool types driven up by cryoturbation from underlying levels? Do (functional) characteristics of the lithic industry underlie the scarcity of backed bladelets and other microliths in the Gravettian levels, or was this simply the result of methodological omissions during excavation? The unraveling of these 
problems will require a more detailed study of Mousterian artifacts and a thorough review of the Vindija stratigraphy, along with further radiometric dating and the detailed study of fauna currently under way. Along with the review of Paleolithic material obtained from other sites in northwestern Croatia (e.g., Velika Pecina), new excavations throughout Hrvatsko Zagorje would be of great importance indeed.đ

\section{NOTES}

1. Vida Pohar (Department of Mining, Faculty of Natural Science and Technology, University of Ljubljana) has given me abundant professional advice, for which I am particularly grateful. I would also like to express my gratitude to my professors, Nives Majnaric-Pandzic and Tihomila Tezak-Gregl (both of the Department of Archaeology, Faculty of Philosophy.University of Zagreb), and to Maja Paunovic (Institute of Paleontology and Quaternary Geology, Croatian Academy of Sciences and Arts) for letting me use Vindija material in my analyses. I am indebted for professional advice to Jakov Radovcic and Darko Rukavina (both of the Department of Paleontology, Croatian Natural History Museum), Jean-Philippe Rigaud (Institut du Quaternaire, University de Bordeaux I), Lawrence Straus and Steve Churchill (both of the Department of Anthropology, University of New Mexico), and Preston Miracle (Museum of Anthropology, University of Michigan). Miljenko Gregl (Department of Archaeology, Faculty of Philosophy, University of Zagreb) prepared the drawings, and Janko Paravic translated this paper into English. Further correction and editing were provided by Straus.

\section{REFERENCES CITED}

Albrecht, G., J. Hahn, and WG. Torke, 1972, Merkmalanalyse von GeschoBspitzen des mittleren Jungpleistozans in Mittel- und Osteuropa. Archaeologica Venatoria. Stuttgart: Verlag W Kohlhammer.

Allsworth-Jones, P, 1986, The Szeletian and the Transition from Middle to Upper Paleolithic in Central Europe. Oxford: Clarendon Press.

Easier, D., 1976, Paleolitsko prebivaliste Badanj kod Stoca (with German summary). Glasnik Zemaljskog Muzeja Bosne i Hercegovine u Sarajevu 29:5-13.

Easier, D., 1979a, Paleolitske i mezolitske regije i kulture u Bosni i Hercegovini. Pp. 331-55 in Praistorija Jugoslavenskih zemalja 1 (ed. by A. Benac). Sarajevo: Svjetlost.

Easier, D., 1979b, Paleolitske i mezolitske regije i kulture u Crnoj Gori. Pp. 387-403 inPraistorija Jugoslavenskih zemalja 1 (ed. by A. Benac). Sarajevo: Svjetlost.

Brodar, M., 1991, Paleolitik Ciganske jame pri Zeljnah (with German summary). ArheoloSki Vestnik 442:23-43. Ljubljana.

Brodar, M., and E Osole, 1979, Paleolitske i mezolitske regije i kulture u Sloveniji. Pp. 159-94 in Praistorija Jugoslavenskih zemalja 1 (ed. by A. Benac). Sarajevo: Svjetlost.

Brose, D.S., and M.H. Wolpoff, 1971, Early Upper Paleolithic Man and Late Middle Paleolithic Tools. American Anthropologist 73:1156-94.

Gorjanovic-Kramberger, D., 1906, Der Diluviale Mensch von Krapina in Kroatien: Ein Beitrag zur Palaoanthropologie. Wiesbaden: Kreidel.

Gorjanovic-Kramberger, D., 1913, Zivot i kultura diluvijalnog covjeka iz Krapine u Hrvatskoj

(with German summary). Djela Jugoslavenske Akademije Znanosti i Umjetnosti 23. Zagreb: Jugoslavenska Akademija Znanosti i Umjetnosti. 
Jelinek, J., 1969, Neanderthal Man and Homo sapiens in Central and Eastern Europe. Current Anthropology 10(5):457-503.

Kurtanjek, D., and V Marci, 1990, Petrografska istrazivanja paleolitskih artefakata spilje Vindije (with English summary). Rad Jugoslavenske Akademije Znanosti i Umjetnosti 449(24):227-38. Zagreb.

Malez, M., 1967, Paleolit Velike pecine na Ravnoj gori u sjeverozapadnoj Hrvatskoj (with German summary). ArheoloSki Radovi i Rasprave Jugoslavenske Akademije Znanosti i Umjetnosti 4-5:7-64. Zagreb.

Malez, M., 1970, Paleolitska kultura Krapine u svjetlu novih istrazivanja (with English and German summaries). Pp. 57-129 in Krapina 1899-1969 (ed. by M. Malez). Zagreb:

Jugoslavenska Akademija Znanosti i Umjetnosti.

Malez, M., 1971, Yugoslavia. Pp. 337-43 in Catalogue of Fossil Hominids, Part II: Europe (ed. by K.R Oakley, B.C. Campbell, and T.I. Molleson). London: The British Museum (Natural History).

Malez, M., 1974, Noviji rezultati istrazivanja paleolitika u Velikoj pecini, Veternici i Sandalji (with German summary). ArheoloSki Radovi i Rasprave Jugoslavenske Akademije Znanosti i Umjetnosti. 7:7-44. Zagreb.

Malez, M., 1975, Die Hohle Vindija: Eine neue Fundstelle fossiler Hominiden in Kroatien. Bulletin Scientifique du Conseil des Academies des Sciences et des Arts de la RSF

Yougoslavie, Section A, 20(5-6): 139-41. Zagreb.

Malez, M., 1978, Novija istrazivanja paleolitika u Hrvatskom zagorju (with German summary). Pp. 6-69 in ArheoloSka istrazivanja u sjeverozapadnoj Hrvatskoj (ed. by Z. Rapanic). Izdanja Hrvatskog Arheologkog DruStva 2. Zagreb: Hrvatsko ArheoloSko Dru§tvo.

Malez, M., 1987, Pregled mezolitickih i paleolitickih kultura na podrucju Istre (with German summary). Pp. $3^{\wedge} 47$ in ArheoloSka istrazivanja u Istri i Hrvatskom primorju (ed. by V Jurkic). Izdanja Hrvatskog ArheoloSkog DruStva 11(1). Pula: Hrvatsko ArheoloSko DruStvo. Malez, M., 1988, Prethistorijske koStane rukotvorine iz spilje Vindije (Hrvatska, Jugoslavia) (with German summary). Radovi Zavoda za Znanstveni Rad Jugoslavenske Akademije Znanosti i Umjetnosti 2:217-52. Varazdin.

Malez, M., and D. Rukavina, 1975, Krioturbacijske pojave u gornjopleistocenskim naslagama pecine Vindije kod Donje Voce u sjeverozapadnoj Hrvatskoj (with German summary). Rad Jugoslavenske Akademije Znanosti i Umjetnosti 371(17):245-65. Zagreb.

Malez, M., and I). Rukavina, 1979, Polozaj naslaga spilje Vindije u sustavu clanjenja kvartara Sireg podrucja Alpi (with German summary). Rad Jugoslavenske Akademije Znanosti i Umjetnosti 383(18):187-218. Zagreb.

Malez, M., H.E Smith, J. Radovcic, and D. Rukavina, 1980, Upper Pleistocene Hominids from Vindija, Croatia, Yugoslavia. Current Anthropology 21(3):365-67.

Malez, M., and H. Ullrich, 1982, Neuere palaanthropologische Untersuchungen am Material aus der Hohle Vindija (Kroatien, Jugoslawien). Palaeontologia Jugoslavia 29:1-44. Zagreb.

Malez, M., and J.C. Vogel, 1970, Die Ergebnisse der Radiokarbonanalysen der quartaren Schichten der Velika Pecina in Nordwest-Kroatien. Bulletin Scientifique du Conseil des Academies des Sciences et des Arts de la RSF Yougoslavie, Section A, 15(11-12):390-91. Zagreb.

Montet-White, A., H. Laville, and A-M. Lezine, 1986, Le pateolithique en Bosnie du 
Nord: Chronologic, environnement et prehistoire. CAnthropologie 90(1):29-88.

Obelic, B., N. Horvatincic, D. Srdoc, I. Krajcar-Bronic, A. Sliepcevic, and S. Grgic, 1994, Rudjer BoSkovic Institut Radiocarbon Measurements XIII. Radiocarbon 36. Zagreb. In press.

Osole, E, 1976, Paleolitik iz Zupanovega spodmola pri Sajevcah (with German summary). Porocilo o Raziskovanju Paleolita, Neolita in Eneolita v Sloveniji 5:7-28. Ljubljana.

Osole, E, 1983, Epigravettien iz Lukenjske jame pri Precni (with German summary). Porocilo o Raziskovanju Paleolita, Neolita in Eneolita v Sloveniji 11:7-32. Ljubljana.

Osole, E, 1991, Betalov spodmol, rezultati paleolitskih izkopavanj S. Brodarja, II. del (with German summary). Porocilo o Raziskovanju Paleolita, Neolita in Eneolita v Sloveniji 18:7-129. Ljubljana.

Pohar, V, 1978, Tipologija in statisticna obdelava mlajSepaleolitskih kamenih orodnih inventarjev (with German summary). Porocilo o Raziskovanju Paleolita, Neolita in Eneolita v Sloveniji 6:7-42. Ljubljana.

Rukavina, D., 1983, 0 Stratigrafiji gornjeg pleistocena s osvrtom na topla razdoblja i njihov odraz u naslagama na podrucju Jugoslavije (with English summary). Rad Jugoslavenske Akademije Znanosti i Umjetnosti 4()4(19):199-221. Zagreb.

Simek, J.E, 1991, Stone Tool Assemblages from Krapina (Croatia, Yugoslavia). Pp. 58-71 in Raw Material Economies among Prehistoric Hunter-Gatherers (ed. by A. Montet-White and S. Holen). Publications in Anthropology 19. Lawrence, Kan.: University of Kansas.

Smith, EH., 1976, The Neandertal Remains from Krapina: A Descriptive and Comparative Study. Reports of Investigations 15. Knoxville: University of Tennessee, Department of Anthropology.

Smith, EH., 1982, Upper Pleistocene Hominid Evolution in South-Central Europe: A Review of the Evidence and Analysis of Trends. Current Anthropology 23(6) :667-703.

Smith, EH., 1984, Fossil Hominids from the Upper Pleistocene of Central Europe and the Origin of Modern Europeans. Pp. 137-209 in the Origins of Modern Humans: A World Survey of the Fossil Evidence (ed. by EH. Smith and E Spencer). New York: Alan R. Liss.

Smith, EH., and J. C. Ahern, 1994, Brief Communication: Additional Cranial Remains from Vindija Cave, Croatia. American Journal of Physical Anthropology 93:275-80.

Smith, EH., C.D. Boyd, and M. Malez, 1985, Additional Upper Pleistocene Human Remains from Vindija Cave, Croatia, Yugoslavia. American Journal of Physical Anthropology 68:37588.

Sonneville-Bordes, D. de, and J. Perrot, 1953, Essai d'adaptation des methodes statistiques au Paleolithique superieur: Premiers resultats. Bulletin de la Socifte Prehistorique Franchise 50:323-33.

Sonneville-Bordes, D. de, and J. Perrot, 1954, Lexique typologique du Paleolithique supeYieur. Bulletin de la Societe Prehistorique Franchise 51(7):327-35.

Sonneville-Bordes, D. de, and J. Perrot, 1955, Lexique typologique du Paleolithique superieur. Bulletin de la Societe" Prehistorique Franchise 52(1-2):76-79.

Sonneville-Bordes, D. de, and J. Perrot, 1956a, Lexique typologique du Paleolithique superieur. Bulletin de la Societe Prehistorique Francaise 53(7-8):408-12.

Sonneville-Bordes, I), de, and J. Perrot, 1956b, Lexique typologique du Paleolithique superieur. Bulletin de la Soci£t£ Prehistorique Franchise 53(9):547-59. 
Srdoc, D., A. Sliepcevic, J. Planinic, B. Obelic, and B. Breyer, 1973, Rudjer Boskovic Institut Radiocarbon Measurements II. Radiocarbon 15(2):435-41. Zagreb.

Srdoc, D., A. Sliepcevic, B. Obelic, and N. Horvatincic, 1979, Rudjer Boskovic Institut Radiocarbon Measurements V Radiocarbon 21(1):131-47. Zagreb.

Straus, L.G., 1989, Age of the Modern Europeans. Nature 342:476-77.

Stringer, C.B., 1982a, Comment on Upper Pleistocene Evolution in South-Central Europe: A Review of the Evidence and Analysis of Trends. Current Anthropology 23(6):690-91.

Stringer, C.B., 1982b, Towards a Solution to the Neanderthal Problem. Journal of Human Evolution 11:431-38.

Turk, I., 1988, KoSceni gumbi iz divjih bab I: Prispevek k razlagi njihovega nastanka (with German summary). Porocilo o Raziskovanju Paleolita, Neolita in Eneolita v Slovenijil6:59-64. Ljubljana.

Valoch, K., 1968, Evolution of the Palaeolithic in Central and Eastern Europe. Current Anthropology 9(5):351-9().

Vukovic, S., 1950, Paleolitska kamena industrija spilje Vindije (with French summary). Historijski Zbornik 1-4:241-56. Zagreb.

Vukovic, S., 1961, Mezolitska kamena industrija spilje Vindije (with German summary). GodiSnjak Gradskog Muzeja Varazdin 1:9-32. Varazdin.

Vukovic, S., 1970. Gravetijen spilje Vindije s osvrtom na gravetijen s podrucja sjeverne Italije, slovenskog Krasa i obale Istre (with German summary). Pp. 31-46 in Adriatica praehistorica et antiqua (ed. by V Mirosavljevic, D. Rendic-Miocevic, and M. Suic). Zagreb: Sveuciliste u Zagrebu, Arheoloski Institut Filozofskog Fakulteta.

Wolpoff, M.H., 1980, Paleoanthropology. New York: A.A. Knopf.

Wolpoff, M.H., H.F Smith, M. Malez, J. Radovcic, and I). Rukavina, 1981, Upper Pleistocene Human Remains from Vindija Cave, Croatia, Yugoslavia. American Journal of Physical Anthropology 54:499-545.

Zupanic, J., 1975, Petrografske karakteristike paleolitskih artefakata iz Sandalje II kod Pule i porijeklo kamene sirovene za njihovu izradbu (with English summary). Rad Jugoslavenske Akademije Znanosti i Umjetnosti 371(17):267-75. Zagreb. 